\title{
Tearing while bowling
}

Pairoj Chattranukulchai, ${ }^{1}$ Kittichai Luengtaviboon, ${ }^{2}$ Monravee Tumkosit ${ }^{3}$

${ }^{1}$ Division of Cardiology, Department of Medicine, Faculty of Medicine, Chulalongkorn University, Cardiac Center, King Chulalongkorn Memorial Hospital, Bangkok, Thailand ${ }^{2}$ Division of Cardiothoracic Surgery, Department of Surgery, Faculty of Medicine Chulalongkorn University, Bangkok, Thailand

${ }^{3}$ Department of Radiology, Faculty of Medicine,

Chulalongkorn University, Bangkok, Thailand

\section{Correspondence to}

Dr Pairoj Chattranukulchai, pairoj.md@gmail.com
To cite: Chattranukulchai $P$, Luengtaviboon $\mathrm{K}$,

Tumkosit M. BMJ Case Rep Published online: [please include Day Month Year] doi:10.1136/bcr-2013-

010389

\section{DESCRIPTION}

A 38-year-old man with asymptomatic chest wall deformity presented with acute, severe retrosternal pain experienced while he was bowling. The pain radiated to the back and down to abdomen in a tearing fashion. Physical examination revealed tall stature, arachnodactyly, marked funnel chest (figure 1A) and severe thoracic scoliosis as demonstrated

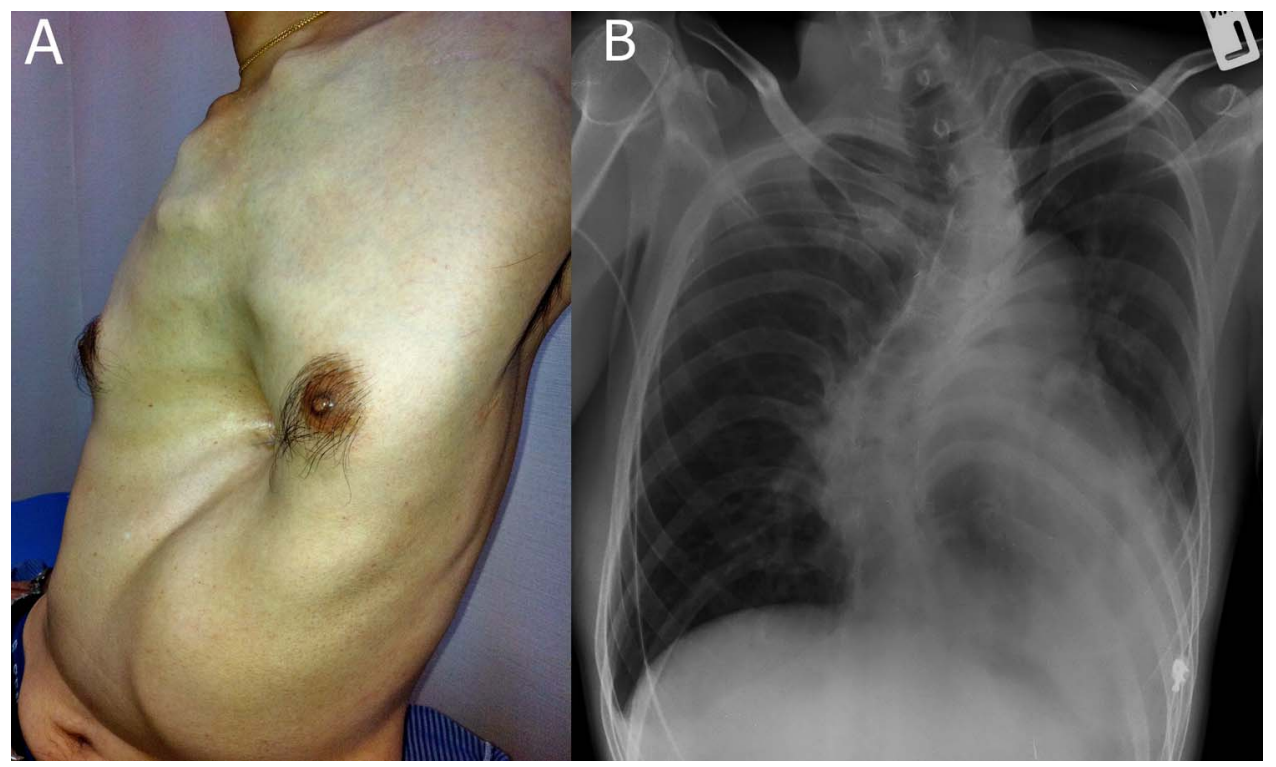

Figure 1 (A) Physical examination reveals marked funnel chest. (B) Chest film shows severe thoracic scoliosis with leftward shift of the heart.

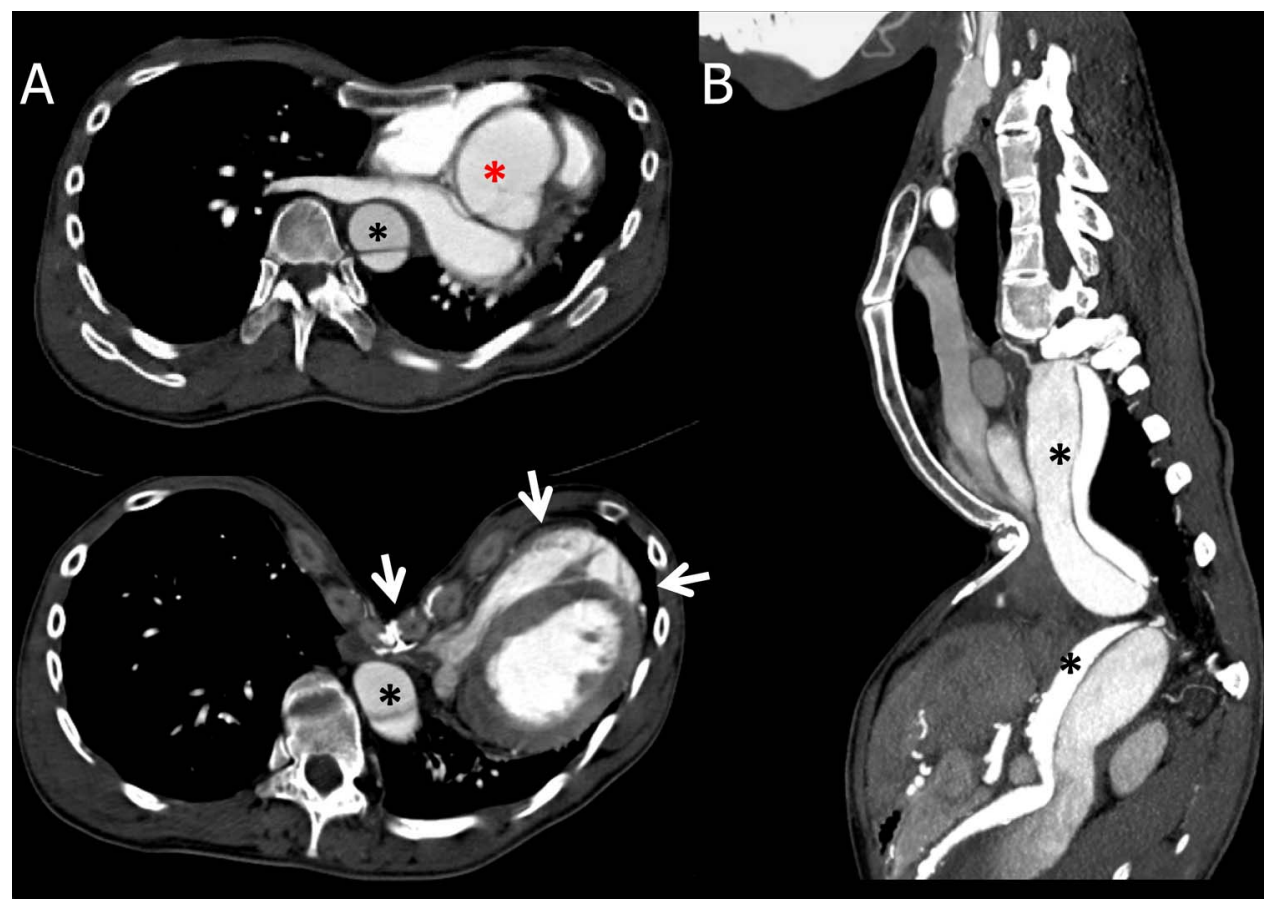

Figure 2 (A) Contrast-enhanced axial CT demonstrate an annuloaortic ectasia of aortic root (red asterix) with intimal flap separates the true from false lumen at descending aorta (black asterisk). Severe pectus excavatum with very short distance between sternum and vertebrae results in complete encompassing of the heart in the left hemithorax

(arrows). (B) Sagittal image also shows the severely depressed sternum and the extent of floating dissection flap along descending aorta, consistent with type B aortic dissection. 
by chest film (figure 1B). He was diaphoretic with blood pressure in both arms were $120 / 80 \mathrm{~mm} \mathrm{Hg}$ where remarkably diminished to $80 / 60 \mathrm{~mm} \mathrm{Hg}$ in both legs. Faint diastolic blowing murmur was heard along the left parasternal border; these factors qprompted the suspicion of aortic dissection.

An echocardiography revealed annuloaortic ectasia with aortic root dilation to $52 \mathrm{~mm}$ associated with mild aortic regurgitation. The dilated descending thoracic aorta with intimal flap was also noted.

A contrast-enhanced axial CT revealed severe pectus excavatum with a very short distance between the sternum and the vertebrae resulting in complete encompassing of the heart in the left hemithorax (figure 2A, arrows). Annuloaortic ectasia (figure $2 \mathrm{~A}$, red asterix) with type $\mathrm{B}$ aortic dissection were confirmed. The intimal flap separated true from false lumen (figure 2, black asterisk) starting from the proximal descending thoracic aorta down to the aortic bifurcation. The sagittal image also demonstrated the severely depressed sternum and the extent of the floating dissection flap (figure 2B).

The patient was diagnosed as having Marfan syndrome-the intrinsic aortic wall weakness predisposing to aneurysm formation and dissection. ${ }^{1}$ Late diagnosis has a negative influence on the outcome. Early detection includes interval monitoring of aortic enlargement by regular imaging of the aorta along with preventive therapies consist of oral $\beta$-blocker along and prophylactic aortic repair when indicated could prevent this catastrophic event. ${ }^{2}$ The patient underwent open aortic repair and his postoperative follow-up was uneventful.

\section{Learning points}

- Marfan syndrome is an inherited disorder of connective tissue.

- Clinical manifestations comprise classic ocular, musculoskeletal and cardiovascular abnormalities which include aneurysm formation and dissection of aorta.

- Early detection including regular imaging of the aorta and timely surgical repair when indicated are crucial to prevent catastrophic aortic dissection.

Contributors $\mathrm{PC}$ was involved in writing the manuscript. $\mathrm{KL}$ and MT reviewed and edited the manuscript.

Competing interests None.

Patient consent Obtained.

Provenance and peer review Not commissioned; externally peer reviewed.

\section{REFERENCES}

$1 \mathrm{Ha} \mathrm{HI}$, Seo JB, Lee SH. Imaging of Marfan syndrome: multisystemic manifestations. Radiographics 2007;27:989-1004.

2 Milewicz DM, Dietz HC, Miller DC. Treatment of aortic disease in patients with Marfan syndrome. Circulation 2005;111:150-7.

\author{
Copyright 2013 BMJ Publishing Group. All rights reserved. For permission to reuse any of this content visit \\ http://group.bmj.com/group/rights-licensing/permissions. \\ BMJ Case Report Fellows may re-use this article for personal use and teaching without any further permission. \\ Become a Fellow of BMJ Case Reports today and you can: \\ - Submit as many cases as you like \\ - Enjoy fast sympathetic peer review and rapid publication of accepted articles \\ - Access all the published articles \\ - Re-use any of the published material for personal use and teaching without further permission \\ For information on Institutional Fellowships contact consortiasales@bmjgroup.com \\ Visit casereports.bmj.com for more articles like this and to become a Fellow
}

